\title{
Use of Electronic Resources by Law Degree Students at Anuradhapura Regional Centre of the Open University of Sri Lanka
}

Karunarathna, H.M.P.P ${ }^{1}$

\begin{abstract}
E- Resources have become a popular information path to academics, teachers and researchers since last decade. This study examined to identify the use of eresources by law degree students at Anuradhapura Regional Centre (ARC) of the Open University of Sri Lanka (OUSL) .The purpose of this study was to identify the purpose and frequency of use of e- resources by law degree students, identify the computer and English language skills of law degree students. Further, to identify problems faced by the students when accessing and using e- resources. Semi structured questionnaire was distributed among 181 law degree students and 115 students $(64 \%)$ responded to this survey. The findings revealed that majority (93\%) of students have been used e- resources but most of them were unaware how to use various e- resources for their academic activities. Further, findings revealed that lack of computer skills and English language skills have also been affected to the usage of e- resources. Their main barrier was insufficient work station with bandwidth. So it is recommended to increase the computer facility at ARC library and develop new courses and training sessions to develop their computer skills and English language proficiency.
\end{abstract}

Keywords: - Electronic resources, Distance learning support services, Computer skills, Law Degree Students

\section{Introduction}

The word 'Information' has been made a significant impact on activities of human being. Information can be defined in various ways, it is that which reduces uncertainty, it is that which assists in decision making, it may exists as data in books, computers, people, files and other resources. With the advancements of the Information and Communication Technology (ICT) the mode of information changed from print base to electronic base. Over the centuries print resources played a major role to fulfil information needs of researchers, teachers, scholars and learners. The development of the invention revolution

\footnotetext{
${ }^{I}$ Assistant Librarian, Open University of Sri Lanka, Sri Lanka.Email: hmkar@ou.ac.lk
} 
has dramatically commenced with the development of ICT. Basically, ICT has recognized as an integral part of the all sectors with the technology development. The sources of information which were available in print format dramatically changed with the ICT advancements.

With the development of new technologies, especially invention of the computers, Internet and World Wide Web (WWW) impact to generate lot of information in the cyberspace. According to the Jacobson (1991) it is quite clear that searching for information has become inexorably linked to computer technology. However before the invention of the WWW, Internet provided only screens of full text. WWW was invented by British scientist Tim Berners Lee in 1990. With the invention of the WWW, Internet has gradually become an easily accessible network for the all communities in the world. However by 2000, digital information retrieve commonly seen and the number of users and the web developers increased day by day. However, in recent years electronic information has been become as a fundamental need of human being. As well as it has become as a major requirement of students, teachers, scholars and researchers. So there are many debates about the proper definition of e- resources.

Electronic resources simply can be defined as computer or mobile device required access resources. Some of them required network connection like Internet. However, e- resources defined by Graham (2003);

The term "electronic resources" does not appear to be used consistently. There may be reference to electronic information services (EIS), electronic information resources or electronic library resources, to mention just some of the available terminology. Therefore, "electronic resources has broadly been defined as, information accessed by a computer that may be useful as bibliographic guides to potential sources but which may also appear as cited references in their own right" (pp.18p-23)

Therefore e- resources are being established as an information access path for discovered through the ICT advancements. This advent has been impact for information services also. Thus e- resources initially used as to known the bibliographic guide. New features, 
opportunities dramatically appeared though the e- resources as a result of the ICT advancements. As a result of that the information available in print format such as, books, journals, reports, thesis and dissertations, indexes, abstracts, dictionaries, encyclopaedia are now available in the electronic format.

According to AACR2, 2005 Update, an e- resource is:

"Material (data and/or program(s)) encoded for manipulation by a computerized device. This material may require the use of a peripheral directly connected to a computerized device (e.g., CD-ROM drive) or a connection to a computer network (e.g., the Internet)." (Anglo-American Cataloging Rules, Second Edition, 2002 Revision.)

In 2007 library of Congress has provided the revised edition of guidelines for coding electronic resources in Leader/ 06 and according to that guidelines e- resources has defined as follows,

"An electronic resource is a manifestation of a work that requires the use of a computer for access. Peripheral devices attached to the computer (such as a CD-ROM drive) may also be required. The manifestation's carrier is accessed either directly (e.g., via CD-ROM, etc.) or remotely (e.g., via the Internet). Items that do not require the use of a computer, such as audio CDs or movies on DVD-videodiscs, are excluded from this definition." (Guidelines for Coding Electronic Resources in Leader/06, Revised December 2007)

The accessibility and the availability of information are increasing day by day in the modern world. The way of searching and delivering of information is vastly changed with the modern technology and with modern equipments. As a result of that use of e-resources has been increased and importance of the e-resources provision is also highlighted among the users.

Electronic Information Resources (e- resources) may be defined as information sources that are available and can be accessed electronically through such computer-networked facilities as online library catalogues, the Internet and the World Wide Web, digital libraries and archives, government portals and websites, CD-ROM databases, online academic databases such as Medline Online, or commercial databases such as LEXIS and NEXIS.

Currently the use of e-resources by university students is remarkable because all Sri Lankan universities have setup E-archives and web base resources with searching facilities. In 
addition to that users are also preferred to use e-resources than printed resources. This was further confirmed by Gunasekera (2012) and Pieris (2012) through their research findings. Library services available in distance mode universities are playing a major role with supplying of new information resources, combined with the new technology. The einformation and e- resources are highly helpful to provide library support service in the distance mode environment.

\section{OUSL Library Network}

The Open University of Sri Lanka (OUSL) is the main university which provides open and distance mode teaching in the country. The OUSL offers programmes from certificate to PhD level. Among the support services, preference is given to library and information services. The OUSL support distance learners thorough the main library, six regional centre libraries and mini libraries that are available at twenty six study centres all over the country. In addition to that online support services are also available through the library website.

\section{E- Resources at OUSL Library}

Information environment is changing extremely, taking new approaches and practical solutions to meet the demand of the modern users. Hence that, library support services and other learning resources should be given to the distance learners as they study alone using lesson materials at their own place. The OUSL library plays a major role in assisting the OUSL to achieve its goals in teaching, learning and research.

With this necessity, librarian as a support service provider has to take necessary steps to improve and increase e- resources. In this initiative the planned activities by main library to increase the facility are digitizing, archiving and providing access to historical and contemporary materials. Its e- resources collection such as digitized past paper collection, subscribed full text e-journal article databases, e- newspapers, e- government publications, e-legal documents, OUSL e-repository, subject related websites, digitized research abstracts, OUSL academic staff research collection. 
Further, Internet browsing facility for educational and research purposes and Open Educational Resources collection (OER) etc., accessible freely URL index, Databases such as ERIC and GIS, Distance Education Journal Abstracts, Theses Abstracts etc.. All e resources can be accessed online through OUSL library web except full text e-journal articles subscribed by the OUSL. Subscribed full text e-journal articles databases can be accessed only through the intranet as they are restricted to IP authenticated computers.

Remote learners who are scattered in the island can access the e-resources through intranet and www using computers available at Virtual Resource Centre (VRC), Colombo Regional Centre Computer Lab (CRCCL) and through other computer labs in each regional and study centres. Further, students can access e- resources through Nodes Access Centre (NAC) and Nanasala centres (Government cybercafé) that are located close proximity to learners residences and working place etc.

Electronic make users into greater contact with library collections and other information sources. In the distance education mode, the necessity of information resources available in the electronic format is beneficial to achieve their learning objectives in connected to modern and updated information.

\section{Services at ARC}

Anuradhapura Regional Centre Library was established in 2009. At the beginning reference facility was available at the ARC library for students and staff but presently lending, photocopying, ILL, referral services are provided for users. Further, ARC students are guided to use e-resources available via library website they can access online resources through the ARC computer lab.

\section{Objectives of the Study}

The objectives of the study were,

$>$ To identify the purpose and frequency of use of e- resources by Law Degree students at ARC 
$>$ To identify the computer literacy skills and English language skills of Law Degree students at ARC

$>$ To find out problems faced by the Law Degree students at ARC, when they access and use e- resources

\section{Literature Review}

With the development of communication technology, there was a major revolution in production and delivery of e-resources. Various e-resources have been introduced to the modern world by various people during the recent years. It was a major task for the librarians to provide their services to the users with the development of information day by day. However, many researchers have evaluated their services and strengthens and weaknesses of e- resources in order to users to provide better service for users. Especially university students are highly familiar with e - resources in modern world due to ICT development. The information needs for higher studies are greater than the secondary education. Further educational institutions have also been introduced e-resources. As a result e-resources are popular among the undergraduates, researchers, teachers, and scholars etc than the printed resources.

Adeyemi (2002) explained that electronic literature was very useful for research students due to the vast amount of data it contains. Tenopir (2003) analyzed results of over 200 studies of the use of e- resources in libraries published between 1995 and 2003. The main conclusion of this review is that electronic resources have been rapidly adopted in academic spheres, though the behavior varies according to the discipline. Ibrahim (2004), Borrego et al. (2007), Sharma (2009), Omotayo (2010), Thanuskodi (2010) have revealed in their research that e- journals were the mostly used resource among other electronic resources. According to the Hadagali et al. (2012) the information content in e- resources is better than that of print versions and most of the users' access e- resources to search bibliographical information. 
Gakibayo, Odongo and Okello-Obura (2013) found that utilization of e-resources was not only affected by lack of computer skills and information literacy skills but also lack of enough computers and slow internet connectivity. The frequency of use of these resources indicated that a lot is needed to be done to increase e-resource use.

However in Sri Lanka there were very few researches which have been done in this field. Gunasekara (2010, 2012), Peirs (2012), Jayasundara (2007) Millawithanchchi (2012) have done researches to evaluate the e- resources use and the e-services.

Gunasekara (2012) has done study on an investigation on use of e- information resources by distance learners at CRC computer lab of the Open University of Sri Lanka. She was identified three major barriers in using e-resources by the students. Accordingly the main personnel barrier they had was lack of English Language Knowledge and the institutional barrier was a time period allocated for students to use the computer lab and the main technical barrier was slow internet speed.

\section{Research Methodology}

\section{Statement of the Problem}

ARC commenced the Law degree programme in 2011 with 105 students. Among all undergraduate programmes, the highest number of students (181) has registered for the LLB (Law Degree program) in the year 2012 at ARC. It was observed that LLB students are rarely coming to the library and few inquires are made. The inquired made and library visit during the period of January to July 2013 by the students are given below. 
Table1: Monthly inquires statistics ARC

\begin{tabular}{|l|c|c|}
\hline \multicolumn{1}{|c|}{ Degree Programme } & Inquires made & Library visits \\
\hline Bachelor of Arts (BA) & 28 & 30 \\
\hline $\begin{array}{l}\text { Bachelor of Management } \\
\text { (BMS) }\end{array}$ & 15 & 35 \\
\hline Bachelor of Science (B.Sc) & 35 & 50 \\
\hline Law Degree & 05 & 15 \\
\hline
\end{tabular}

Based on the statistics the researcher had informal discussions with them to reveal the reasons for lack of use the library. It was found that they use online resources for their study purposes. But further it was revealed that through discussions awareness of the availability of e- resources for the academic purposes is low. University is spending lot of money annually to provide online resources and support services to distance learners hoping to produce skilful graduates. Therefore, use of e-resources is very important for the academic needs as students cannot survive in the modern society without e- resources. However no research has been carried out to evaluate the awareness about the availability of e-resources by LLB students, usage of them and to understand the strengths and weaknesses of the service. Therefore, it is important to identify purpose of use of eresources and strengths and weaknesses of the services given to them.

\section{Population and Sample}

The population of the study is distance learners who follow Bachelors degree programes at the OUSL.

The sample for the study was LLB students who are registered to follow the Law Degree programme at the ARC. All students who registered for the Law degree programme in 2012 was 181 and all students were selected as the sample for the study. (New registered - 
94 and reregistered 87) The reason is that they are the highest number of students who registered for the degree programme At ARC in 2012. Number of student who registered for the LLB is increasing annually. Therefore, it is important to pay more attention for them and evaluate their information seeking behavior to introduce more facilities, and resources. Therefore, all LLB students who are studying at ARC were selected for the sample.

\section{Research Method, Data Collection and Data Analysis}

The survey method was used for the study and semi structured questionnaire was used to collect data.The collected data through questionnaires were fed in to MS excel and frequency were calculated to analyze the collected data.

\section{Results and Discussion}

\section{Analysis of Respondents' Demographic Information}

Out of the 181 questionnaires that have been sent, researcher was able to obtained $64 \%$ (115) response rate from the Law Degree students.

\section{Gender Distribution of the Respondents}

Table 2: Gender distribution of the respondents $(\mathrm{N}=115)$

\begin{tabular}{ccc}
\hline Gender & Frequency & Percentage \\
\hline Male & 74 & $64 \%$ \\
Female & 41 & $36 \%$ \\
Total & 115 & $100 \%$ \\
\hline
\end{tabular}

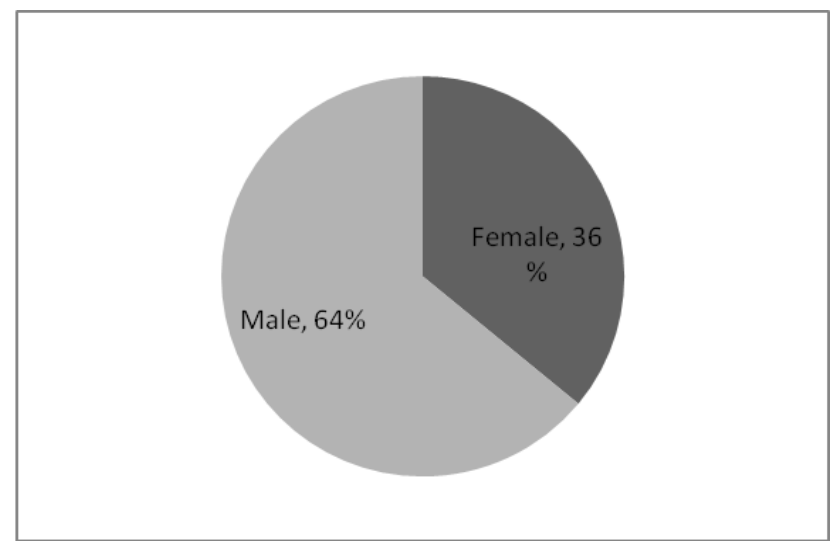


Figure 1: Gender distribution of the respondents

According to the gender distributions of the s

respondents were female (36\%). (See the table 2 and figure 1 )

\section{Age Distribution of the Respondents}

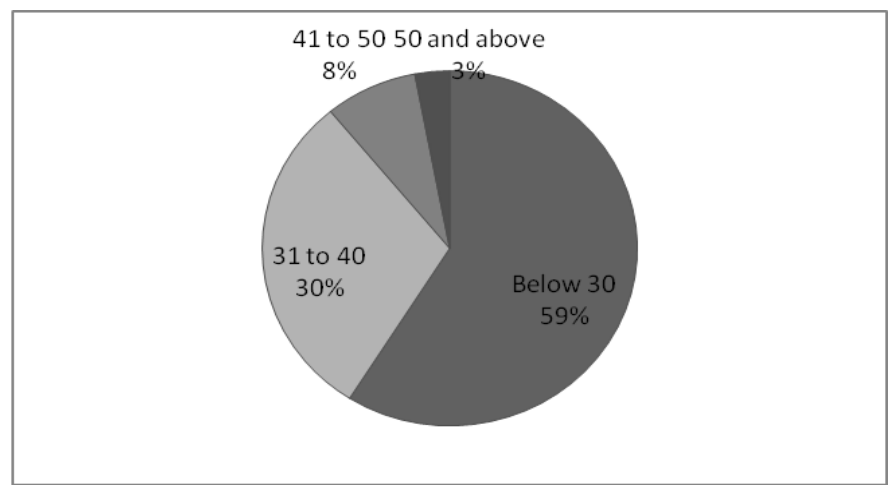

Figure 2: Age distribution of the respondents

As shown in the figure 2, majority of respondents were in below 30 years age group and amounted for $59 \%$. Between 31 to 40 age group was $30 \%$ and 41 to 50 age group was $8 \%$ and 50 and above $3 \%$ of them.

\section{Marital status of the Respondents}

Table 3: Marital status of the respondents

\begin{tabular}{lcc}
\hline Status & Frequency & Percentage \\
\hline Married & 43 & $37 \%$ \\
Single & 71 & $62 \%$ \\
Divorced & 1 & $1 \%$ \\
Total & 115 & $100 \%$ \\
\hline$(\mathrm{N}=115)$ & &
\end{tabular}


As shown in the table 3, the marital status of the respondents ; 62\% of the respondents were unmarried while $37 \%$ were married. It was found that only one respondent was divorced.

\section{Analysis of respondents' Skills on Use of E- Resources}

\section{Computer Skills}

Table 4: Computer skills of Law degree students

\begin{tabular}{ccc}
\hline Rank & Frequency & Percentage \\
\hline $\begin{array}{c}\text { Very } \\
\text { Good } \\
\text { Good }\end{array}$ & $\mathbf{2 0}$ & $17 \%$ \\
Average & 32 & $\mathbf{4 0} \%$ \\
Poor & 17 & $15 \%$ \\
Non & 0 & $0 \%$ \\
Total & 115 & $100 \%$ \\
\hline
\end{tabular}

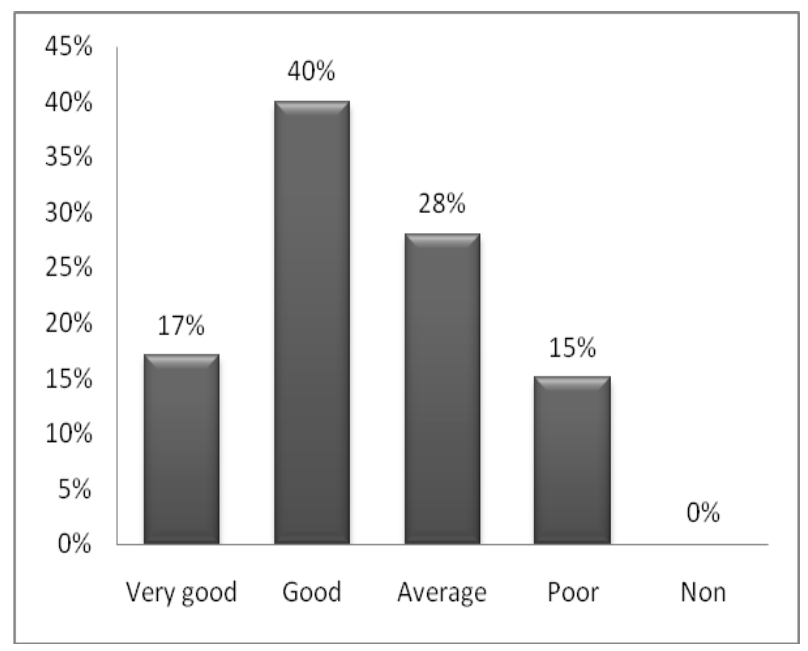

$(\mathrm{N}=115)$

Figure 3: Computer skills of Law Degree students

Respondents were asked to rank their computer knowledge and Table 4 and the Figure 3 show the respondents' self - perceived computer knowledge level. Majority of them said their computer knowledge was good and amounted to $40 \%$, and $28 \%$ average and $17 \%$ said it was very good and $15 \%$ of them said that they are weak in using computers. It was also found that there were no any respondents who weak to use computer. 


\section{English Proficiency}

Table 5: English

Language skills of Law Degree Students

\begin{tabular}{ccc}
\hline Rank & Frequency & Percentage \\
\hline Very Good & 13 & $11 \%$ \\
Good & 47 & $41 \%$ \\
Average & 40 & $35 \%$ \\
Poor & 14 & $12 \%$ \\
Non & 1 & $1 \%$ \\
Total & 115 & $100 \%$ \\
\hline
\end{tabular}

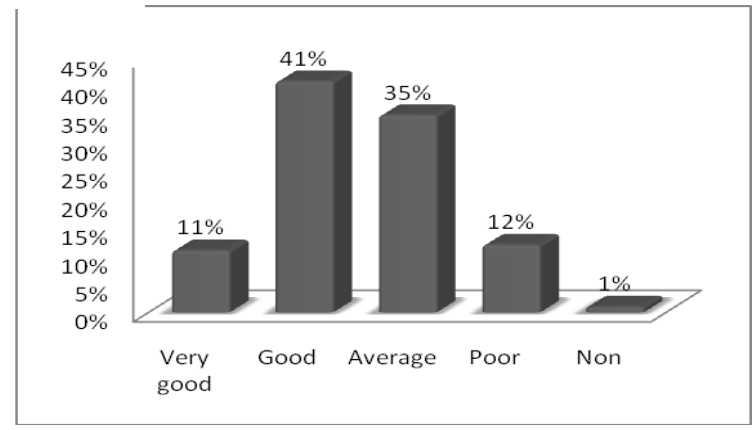

$(\mathrm{N}=115)$

Figure 4: English proficiency of Law Degree Students

Table 5 and the Figure 4 show the level of English language skills of respondents and most of them (41\%) said that their English language skills was good. 35\% of them said they have average knowledge of English language skills and $12 \%$ of respondents weak. It was able to find that $11 \%$ of them had very good English language proficiency while $1 \%$ said that they do not have any English language skills.

\section{Analysis of Respondents' Usage of E- Resources}

\section{Use of E- Resources}

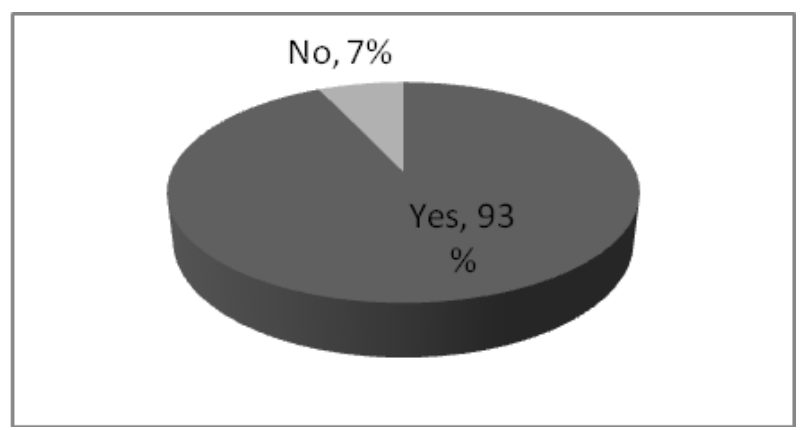

Figure 5: Use of e- resources $(\mathrm{N}=115)$ 
Figure 5 shows the level of usage of e- resources by Law Degree students. Out of 115 respondents, 107 used e- resources, which is $93 \%$ of the total respondents and 8 respondents which is $7 \%$ of the total did not use e- resources. Accordingly the majority of them used e- resources.

\section{Frequency of Use of E- Resources}

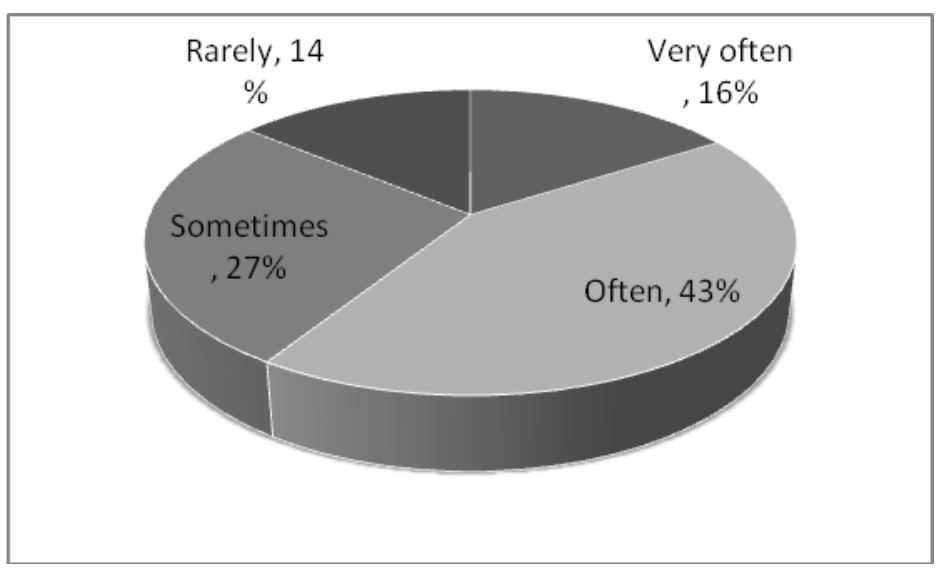

Figure 6: Frequency of use of e- resources $(\mathrm{N}=107)$

Frequency of use of e- resources by Law degree students' was presented in Figure 6 . Majority of them often used e- resources and amounted 43; 27\% of them sometimes used eresources and $16 \%$ of them used very often and it was able to find that $14 \%$ of them used eresources rarely. The results of frequency of use of e- resources revealed that the most of respondents often used e- resources. 


\subsubsection{Place of Access of E- Resources}

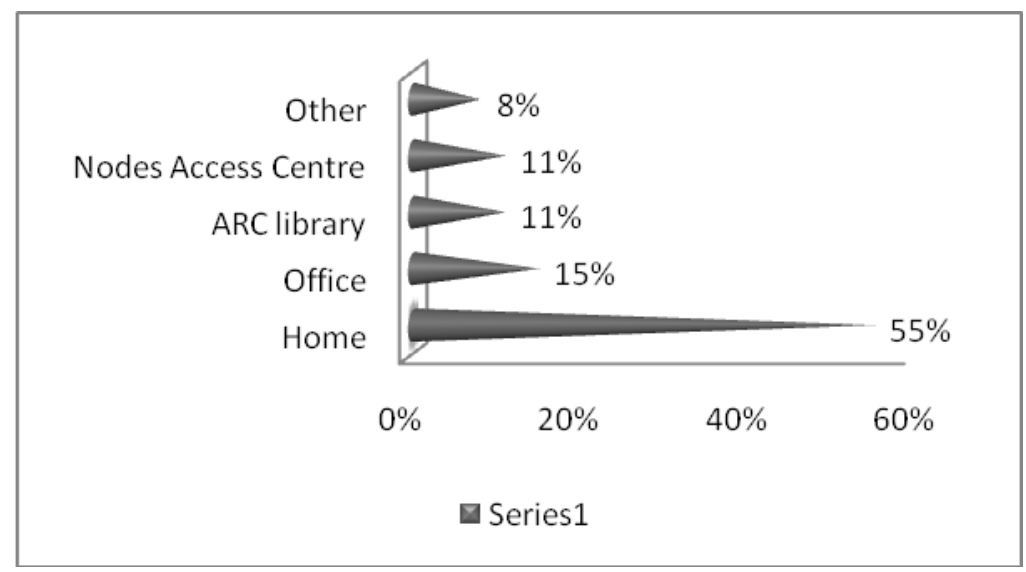

Figure 7: Place of access of e- resources $(\mathrm{N}=107)$

Figure 7 has shown the place of access of e- resources by Law degree students. The higher percentage $(55 \%)$ of them used e-resources at home while 15 of the respondents access eresources at the office or where they work; $11 \%$ of the respondents used the ARC library and the same percentage is seen for those used Nodes Access Centre. The lowest percentage $(8 \%)$ used other places. As the distance learners majority of them used home and the office as the access point.

\section{Purpose of Using E- Resources}

Table 6: Purpose of using e- resources $(\mathrm{N}=107)$

\begin{tabular}{|c|c|c|c|c|c|c|c|c|c|}
\hline $\begin{array}{c}\text { Serial } \\
\text { No }\end{array}$ & Purpose & \multicolumn{2}{|c|}{ Highly Use } & \multicolumn{2}{|c|}{$\begin{array}{l}\text { Moderately } \\
\text { Use }\end{array}$} & \multicolumn{2}{|c|}{ Poor } & \multicolumn{2}{|c|}{ Never } \\
\hline 01 & To write assignments & 28 & $26 \%$ & 31 & $29 \%$ & 26 & $24 \%$ & 22 & $21 \%$ \\
\hline 02 & To make class presentations & 23 & $21 \%$ & 35 & $33 \%$ & 22 & $21 \%$ & 27 & $25 \%$ \\
\hline 03 & $\begin{array}{l}\text { To further references of } \\
\text { studies }\end{array}$ & 25 & $23 \%$ & 48 & $45 \%$ & 18 & $17 \%$ & 16 & $15 \%$ \\
\hline 04 & $\begin{array}{l}\text { To prepare for the } \\
\text { examinations }\end{array}$ & 19 & $18 \%$ & 41 & $38 \%$ & 30 & $28 \%$ & 17 & $16 \%$ \\
\hline 05 & Personal use & 45 & $42 \%$ & 24 & $22 \%$ & 20 & $19 \%$ & 18 & $17 \%$ \\
\hline 06 & Other & 24 & $22 \%$ & 34 & $32 \%$ & 19 & $18 \%$ & 30 & $28 \%$ \\
\hline
\end{tabular}


Table 6 has shown the purposes of using of e- resources by Law degree students. According to the table 5 participants have different kind of purposes of using e- resources. The purpose of using e- resources ranked four scales as highly used, moderately used, poor used and never used. Majority of (42\%) of respondents highly used e- resources for the personnel use; $45 \%$ moderately used to further references of studies; for the preparing for the examinations $28 \%$ poorly used e- resources.

\section{Types of E- Resources Used by LLB students}

Table 7 has shown the usage of different types of e- resources by Law degree students.

Table 7: Types of e- resources used by LLB students

\begin{tabular}{|c|c|c|c|c|c|c|c|c|}
\hline Type & \multicolumn{2}{|c|}{ Highly } & \multicolumn{2}{|c|}{ Moderately } & \multicolumn{2}{|c|}{ Poor } & \multicolumn{2}{|c|}{ Never } \\
\hline E-journals & 19 & $18 \%$ & 36 & $34 \%$ & 29 & $27 \%$ & 23 & $21 \%$ \\
\hline E- databases & 16 & $15 \%$ & 37 & $35 \%$ & 29 & $27 \%$ & 25 & $23 \%$ \\
\hline E- dictionaries & 19 & $18 \%$ & 40 & $37 \%$ & 28 & $26 \%$ & 20 & $19 \%$ \\
\hline E- books & 22 & $21 \%$ & 28 & $26 \%$ & 31 & $29 \%$ & 26 & $24 \%$ \\
\hline E- indexes & 22 & $21 \%$ & 26 & $24 \%$ & 32 & $30 \%$ & 27 & $25 \%$ \\
\hline E- chapters & 21 & $20 \%$ & 26 & $24 \%$ & 31 & $29 \%$ & 29 & $27 \%$ \\
\hline E- abstracts & 24 & $22 \%$ & 21 & $20 \%$ & 32 & $30 \%$ & 30 & $28 \%$ \\
\hline E-blogs & 22 & $21 \%$ & 32 & $30 \%$ & 26 & $24 \%$ & 27 & $25 \%$ \\
\hline $\begin{array}{l}\text { E- thesis and } \\
\text { dissertation }\end{array}$ & 22 & $21 \%$ & 25 & $23 \%$ & 26 & $24 \%$ & 34 & $32 \%$ \\
\hline $\begin{array}{c}\text { Online Public } \\
\text { Access } \\
\text { Catalogue }\end{array}$ & 22 & $21 \%$ & 25 & $23 \%$ & 26 & $24 \%$ & 34 & $32 \%$ \\
\hline Other & 21 & $20 \%$ & 31 & $29 \%$ & 27 & $25 \%$ & 28 & $26 \%$ \\
\hline
\end{tabular}

$(\mathrm{N}=107)$ 
Respondents were asked to rank the use of different types of e- resources. Majority of respondents moderately used e- journals and it was 36 (34\%) of them and then $29(27 \%)$ poorly used e- journals

According to the table 7, majority (35\%) of respondents used e- databases moderately and e- dictionaries also majority (37\%) of participants used them moderately. The use of ebooks by Law degree students is comparatively different with other types of e- resources. $29 \%$ of participants were weak in use e- books and it is same to the e- indexes. It was able to find that $30 \%$ of participants were weak in use of e-indexes. As well as $29 \%$ of respondents were weak in use of e- chapters and the $30 \%$ of participants were also weak in use e- abstracts. 30\% of respondents moderately used e- blogs. Majority of (32\%) never used e- thesis and dissertations and it is same to the OPAC; $32 \%$ never used OPAC and the other e- resources $29 \%$ moderately used.

\section{Satisfaction with E- Resources}

Respondents were asked to rank what extent they were satisfied with the e- resources. Figure 8 has shown the results of satisfaction on e- resources by Law degree students.

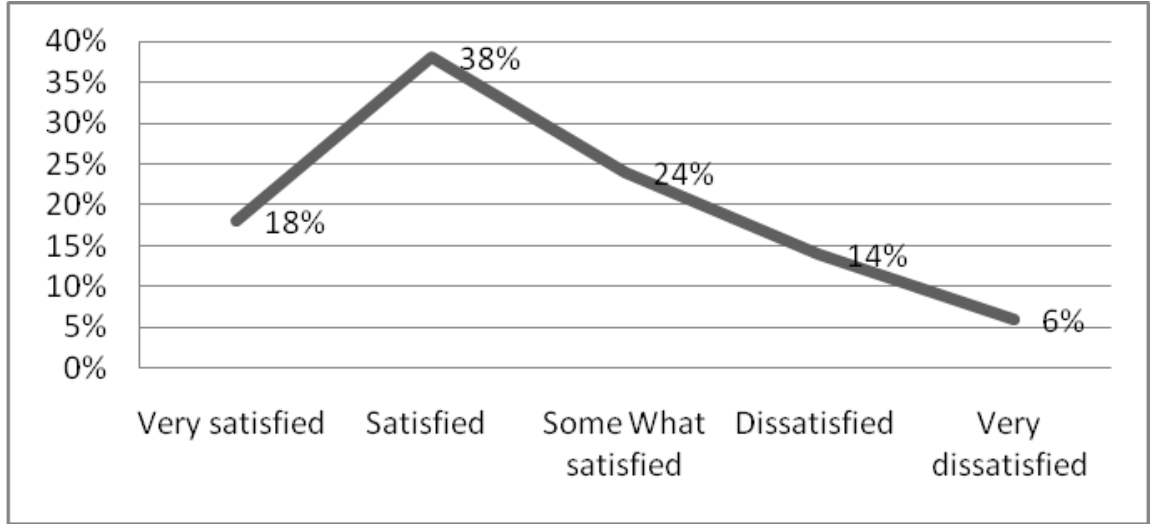

Figure 8: Satisfaction with e- resources $(\mathrm{N}=107)$ 
According to that majority (38\%) of them were satisfied with e- resources and $24 \%$ of them somewhat satisfied and most significant thing is $18 \%$ of them were highly satisfied with e- resources. However $14 \%$ of them said that they dissatisfied with the e- resources and $6 \%$ of them indicated that they highly dissatisfied with e- resources. The present study reveals that most of them satisfied with e- resources and it is beneficial to students to achieve their learning objectives with positive attitude.

\section{Analysis of Barriers to Access E- Resources}

\section{Barriers to Access E-Resources}

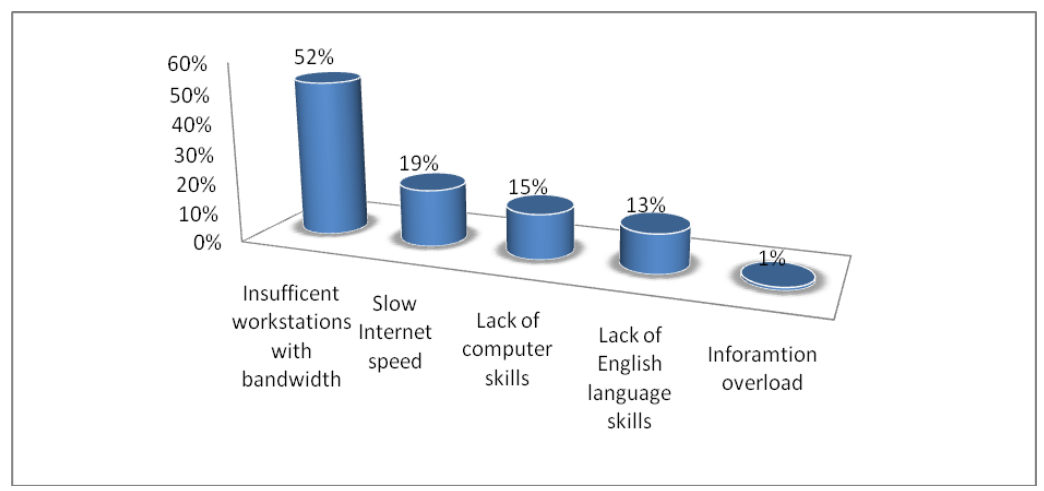

Figure 9: Barriers to access e- resources $(\mathrm{N}=107)$

Figure 9 has shown a picture of Law degree students' opinion on barriers to access eresources. The majority $(52 \%)$ of respondents indicated that main barrier was insufficient workstations with bandwidth; $19 \%$ of them indicated as obstacle of slow internet speed and $15 \%$ of them stated lack of computer skills was a barrier to access to e- resources. $13 \%$ of them indicated lack of English language skills was a barrier and $1 \%$ of them stated information overload was the barrier to use of e- resources.

\section{Discussion and Recommendations}

According to results revealed the majority of respondents have been used e- resources for their purpose of personal use. However it is evident that this result badly affect to their academic career. The present study reveals that majority of respondents have meager used 
e- resources such as e- books, e- chapters, e- indexes, e- abstracts. Most of respondents never used some of e- resources such as E- thesis and dissertations and OPAC s. This may be affected that students' lack of aware or lack of skills to use various e- resources and the importance for their academic activities by using various e- resources. It may also be an obstacle for students to achieve their learning objectives. Hence it is suggested that the use of e- resources should be increased for the academic purposes. Therefore orientation programmes, training programmes should be introduced at ARC library to enhance the usage of e- resources by LLB students.

This study shows that ARC Law Degree students 'situations are diverse in terms of English language skills and computer skills. In this study,lack of computer skills (15\%) and the lack of English Language skills (13\%) were barriers to students to use e- resources since most of electronic resources are available in English language. Fordjour, Badu and Adjei (2010) stated that poor performance of students in the universities had been attributed to their inability to effectively retrieve information for academic work. This conclusion is very important because in this study was found that majority of students moderately used edictionaries. It's mean that most of them needed to search the meaning of certain word or phrase etc. Therefore, more attention should be paid to develop English language skills and computer literacy programs catering Law Degree students.

The present study reveals that most of LLB students have used e- resources at home. The main barrier indicated by students was insufficient workstations with low bandwidth. The ARC library has not sufficient workstations to provide infrastructure facilities to use eresources at the library. As well as without basic computer skills it is difficult to use eresources. The present study reveals that lack of computer skills was also a barrier to use eresources. Anuradhapura Regional Centre has computer laboratory but it is difficult to reserve a computer for other students because of the large number of computer literacy students and Nodes Access Centre at ARC also reserved for many programmes during the weekends. As the distance learners, the day schools are conducting most probably in 
weekends. Hence best alternative; should be increased the amount of computers at ARC library. Because ARC library is located in a calm and quiet atmosphere and there is no other alternative with the space of ARC building at the moment. And especially it should be introduced practical training sessions to use computer for the students.

\section{Conclusion}

Today with the arrival of new technology the users' retrieval of information has been changed and e- resources are playing a key role among the information sources amidst academicians, teachers and researchers. In conclusion it can be said that this study provides a way to improve the usage of e- resources of Law Degree students for the academic purposes and using various e- resources for the academic needs of Law Degree students.

Develop new workshops and information literacy programmes are essential to increase the use of e- resources of Law Degree students and especially two key skills of students should be improved to use e- resources. Therefore new training sessions and new courses should be introduced to improve their computer skills and the English language skills. Further it should be increased the computer facility at ARC library to use for the students with high bandwidth.

\section{References}

Adeyemi, B.M. (2002). Problems and challenges of automating cataloguing process at Kenneth Dike Library. African Journal of Library, Archives and Information Sciences, 12 (2), 213-222.

Borrego, A., et al. (2007). Use and users of electronic journals at Catalan Universities: The results of a survey. Journal of Academic Librarianship. 33(1). Retrieved from http://www.agInternetwork.org.

Fordjour, R., Badu, E.E, and Adjei, E. (2010). The prospects and challenges of information retrieval by university students: a case study of post graduate students of the University of Ghana, Legon. Retrieved from http://ageconsearch.umu.edu/bitstream/9683/2/119.1 information retrieval by university students in Ghana.pdf.(accessed June 9, 2011). 
Gakibayo, A. , Ikoja-Odongo, J. R., \& Okello-Obura,C. (2013). Electronic information resources utilization by students in Mbarara university library. Library Philosophy and Practice (e-journal), paper 869 . Retrieved from http://digitalcommons.unl.edu/cgi/viewcontent.cgi?article=2055\&context=libphilpr ac (accessed 20 June 2013).

Graham, S.R. (2003). Historians and electronic resources: a citation analysis. JAHC, 3(3), 18-24.

Gunasekera, D. (2012). An investigation on use of e-information resources by distance learners at CRC computer lab of the Open University of Sri Lanka, $3^{\text {rd }}$ International symposium on Emerging Trends and Technologies in Libraries and Information Services, New Delhi, pp.569-578.

Gunasekera, D. ( 2010) . Usage of virtual resource centre of the Open University of Sri Lanka: distance learner experience. In S.Katariya, J.P.K. Ambu, and S.Ram (Eds), Proceeding of the $2^{\text {nd }}$ ETTLIS international symposium on Emerging technologies and change in dimension of libraries and information services held at JUIT Waknaghad, June 2010 ( pp.252-256).

Hadagali, G. S., Kumbar,B. D., Nelogal, S. B. \& Bachalapur, M. M. (2012). Use of electronic resources by post-graduate students in different universities of Karnataka State. International Journal of Information Dissemination and Technology, 2(3), 189-195.

Ibrahim, A.E. (2004). Use and user perception of electronic resources in the United Arab Emirates University (UAEU). Libri,54, 21-23

Jacobson, F.F. (1991). Gender differences in attitudes toward using computers in libraries: an exploratory study. Library and Information Studies Research, 13,267279.

Jayasundara, C. (2007). An identification of critical success factors (CSFS) on user perspectives in diffusing e-information service in the university of Colombo library, Sri Lanka Journal of Librarianship and Management, 2 (2), 1-12.

Millawithanchchi, U.S. (2012). Electronic resources usage by postgraduates at the University of Colombo: identifying the critical success factors, Annals of Library and Information Studies, 59,53-63. 
Omotayo, B.O. (2010). Access, use, and attitudes of academics toward electronic journals: A case study of Obafemi Awolowo University, Ile Ife. Library Philosophy and Practice. Retrieved from http://unllib.unl.edu/LPP/omotayo.html

Peiris, N.D \& Peiris, B.L . (2012). An assessment of undergraduate students' usage of eresources to fulfil their information needs: a case study at university of Peradeniya. Sri Lanka Library Review, 26, 30-43.

Sharma, C. (2009). Use and impact of e-resources at Guru Gobind Singh Indraprastha University (India): A case study. Electronic Journal of Academic and Special Librarianship, 10(1), 3-8.

Tenopir, C. (2003). Use and users of electronic library resources: an overview and analysis of recent research studies. Retrieved from http://www.clir.org/pubs/reports/pub120.pdf (accessed 13 June 2012).

Thanuskodi, S. (2010). Use of Internet and electronic resources for medical science information: A case study. Journal of Communication 1(1): 27-44.

The Library of Congress (2012). Anglo American Cataloguing Rules ( $2^{\text {nd }} e d$.), 2002 revision (2005). Retrieved from http://desktop.loc.gov/ (accessed January 6, 2012)

The Library of Congress, (2007) Guidelines for Coding Electronic Resources in Leader/06, Revised December 2007. Retrieved from http://www.loc.gov/marc/ldr06guide.html (accessed February 7, 2012) 